УДК 902.904

МРНТИ 03.41.91

\title{
РЕЦЕНЗИЯ НА КНИГУ: АЗЕРБАЙДЖАН НА ШЕЛКОВОМ ПУТИ Баку: Изд-во «Tahsil», 2020. 384 с.
} Бауыржан Абишевич Байтанаев ${ }^{1}$

${ }^{1}$ доктор исторических наук, академик НАН РК, директор Института археологии им. А. Х. Маргулана, г. Алматы, Казахстан. E-mail: baytanaev@mail.ru

Аннотация. В рецензии дана положительная оценка новому изданию, посвященному изучению актуальной темы - истории Великого Шелкового пути. Книга подготовлена авторским коллективом, состоящим из археологов, историков, востоковедов и архитекторов. Руководителем проекта и научным редактором книги является известный и в нашем регионе специалист в области изучения Шелкового пути, академик Национальной Академии наук Азербайджана Ш. М. Мустафаев. Книга подготовлена и издана при поддержке Международного Фонда тюркской культуры и наследия. Рецензируемая книга является первым опытом анализа влияния Шелкового пути на процесс исторического развития Азербайджана на протяжении всего периода его функционирования от античности до позднего средневековья.

Ключевые слова: Азербайджан, Великий Шелковый путь, археология, древность, средневековье, торгово-экономические связи

\section{ЖІБЕК ЖОЛЫНЫН БОЙЫНДАҒЫ ӘЗЕРБАЙЖАН: КІТАПКА СЫН-ПІКІР Баку: «Tahsil» баспасы, 2020. 384 б.}

\section{Бауыржан Әбішұлы Байтанаев ${ }^{1}$}

\footnotetext{
${ }^{1}$ тарих ғылымдарының докторы, ҚР ҰҒА академигі, Ә. Х. Марғұлан атынд. Археология институтының директоры, Алматы қ-сы, Қазақстан. E-mail: baytanaev@mail.ru
}

\footnotetext{
Аннотация. Пікірде өзекті тақырыпқа - Ұлы Жібек жолының тарихына арналған жаңа басылымға оң баға берілген. Кітапты археологтар, тарихшылар, шығыстанушылар мен сәулетшілерден тұратын авторлық ұжым дайындаған. Жобаның жетекшісі және ғылыми редакторы біздің өлкеде Жібек жолын зерттеу саласы бойынша танымал маман, Әзербайжан Ұлттық ғылым академиясының академигі Ш. М. Мустафаев. Кітап Халықаралық түркі мәдениеті мен мұрасы қорының қолдауымен дайындалып, жарыққа шыққан. Пікір беріліп отырған кітап сонау антикалық кезеңнен кейінгі ортағасырлық аралықтағы Әзербайжанның тарихи даму үрдісіне Жібек жолының ықпалын талдаудың алғашқы тәжірибесі болып табылады.

Түйін сөздер: Әзербайжан, Ұлы Жібек жолы, археология, ежелгі, ортағасыр, сауда-экономикалық байланыстар
} 


\title{
BOOK REVIEW: AZERBAIJAN ON SILK ROAD Baku: Publishing house "Tahsil", 2020. 384 pages
}

\author{
Bauyrzhan A. Baitanayev ${ }^{1}$ \\ ${ }^{1}$ Doctor of Historical Sciences, Academician of the National Academy of Sciences of the \\ Republic of Kazakhstan, Director of the A. Kh. Margulan Institute of Archaeology. \\ Almaty, Kazakhstan. E-mail: baytanaev@mail.ru
}

\begin{abstract}
The review gave a positive assessment to the new publication devoted to the study of the trending topic - the history of the Great Silk Road. The book was prepared by an author's team consisting of archaeologists, historians, orientalists and architects. The project leader and scientific editor of the book is a well-known specialist in the field of Silk Road studies in our region, academician of the National Academy of Sciences of Azerbaijan Sh. M. Mustafaev. The book was prepared and published with the support of the International Fund for Turkic Culture and Heritage. The peer-reviewed book is the first experience of analyzing the influence of the Silk Road on the process of historical development of Azerbaijan throughout its functioning from antiquity to the late Middle Ages.
\end{abstract}

Keywords: Azerbaijan, Great Silk Road, archaeology, antiquity, Middle Ages, trade and economic ties

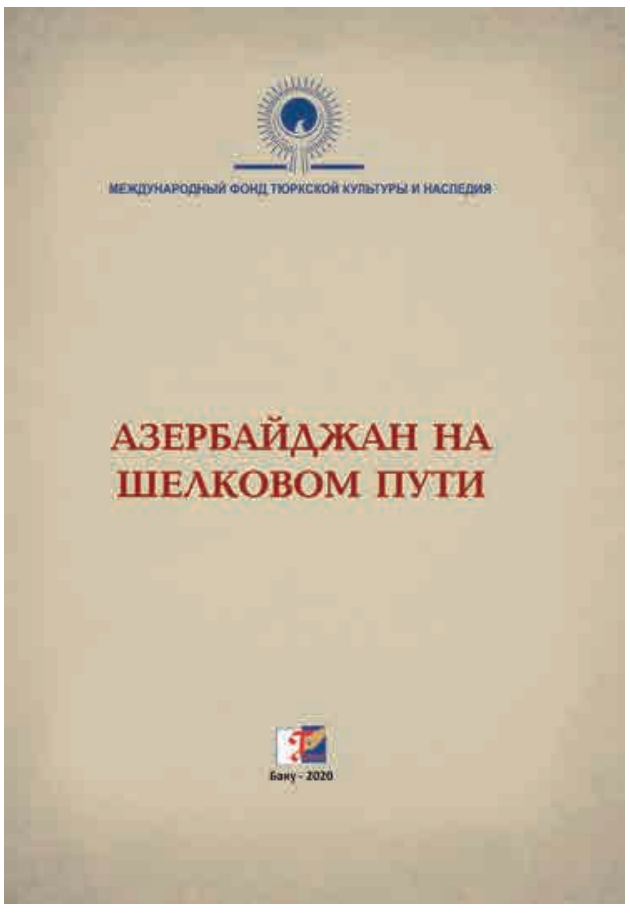

Идея возрождения Великого Шелкового пути (ВШП) в новых современных исторических условиях и превращения его в важный аспект мировых интеграционных процессов, появившаяся в 80-е годы XX в. наряду с разработкой и реализацией многочисленных конкретных проектов по созданию на протяжении всех её исторических трасс благоприятных условий для двухстороннего потока сырья, товаров, информации, научного, культурного обмена и туристических услуг, породило ещё и значительный интерес к истории формирования и функционирования самого пути в древности и в средневековье. Во многих странах практически на всём огромном Евразийском пространстве, в том числе и у нас в Казахстане, изучаются различные научные аспекты этого удивительного явления в истории человечества. Исследованию отдельных конкретных проблем истории ВШП в различных странах посвящено множество книг и научных статей, проведены многочисленные международные конференции, и этот процесс продолжает развиваться.

Считаю, что одним из значимых событий в данном контексте можно с полным основанием считать изданную в 2020 г. в Баку фундаментальную работу «Азербайджан на Шелковом пути». 
Во введении данной книги дан экскурс в историю реализации под эгидой ЮНЕСКО широкомасштабной международной программы под названием «Комплексное исследование Шелкового пути - пути диалога», показаны основные достижения этой программы за время ее реализации и степень вовлеченности Азербайджана, на территории которого находится немало исторических памятников, связанных с ВШП.

Книга состоит из шести глав. В первой главе дан краткий обзор возникновения и развития торговоэкономических связей в Переднеазиатском и Средиземноморском регионах, показаны основные этапы развития торговли в древней Месопотамии, Египте, Вавилоне, Финикии, Греции и в Ахеменидском Иране, освещаются торгово-экономические связи древних племён и ранних государств на территории исторического Азербайджана. Особое внимание в этой главе уделено формированию в Ахеменидский период особого торгового пути из Индии через Центральную Азию и Каспийское море в пределы Южного Кавказа, где далее по рекам Кура, а затем Риони, эта торговая трасса, пройдя с востока на запад, через весь южнокавказский регион, выходит к берегам Чёрного моря, где располагались многочисленные греческие эмпории. Этот торговый путь, известный в научной литературе как «дорога Страбона», впоследствии, став одной из трасс Великого Шелкового пути, играл важную роль в истории торгово-экономических связей всего Южного Кавказа, на протяжении всей античности. В главе показан процесс и условия соединения торговых трасс Средиземноморья, Передней и Центральной Азии, окончательно сложив- шихся в единую торговую систему в эпоху эллинизма, с аналогичными торговыми системами Дальнего Востока, которые быстро сформировались после образования в Китае централизованного государства династии Цинь. Соединение этих международных торговых путей и стало во второй половине II в. до н.э. началом функционирования Шелкового пути.

Последующие пять глав рецензируемой книги выстроены в историко-хронологической последовательности. Авторы во второй главе исследуют античный период, когда региональные маршруты Шелкового пути, проходившие через территорию существовавших тогда на исторических землях Азербайджана государств Атропатена и Албания, во многом определились борьбой двух мощных империй древности - Парфии и Рима.

В раннесредневековом периоде (III-VII вв.), которому посвящены третья и четвёртая главы книги, интенсивность и направления маршрутов ВШП в исследуемом регионе во многом определялись политикой и взаимоотношениями, складывавшимися между Сасанидским Ираном с Римской, а затем с Византийской империями и раннетюркскими государствами. На следующем этапе раннего средневековья (VIII-X вв.) наступило время хазаро-арабского доминирования на Шелковом пути и взаимоотношения между этими государствами во многом определяли степень и вектор направления различных маршрутов ВШП в раннесредневековых государствах Азербайджана. Последние пятая и шестая главы книги, соответственно, освещают сельджукский (XI - начало XIII в.), монгольский и постмонгольский периоды (XIII-XV вв.). В них, как и в предыдущих главах, развитие 
международной торговли Азербайджана, вовлеченность его государств и городов в процессе торговли по маршрутам Шелкового пути опятьтаки даётся на фоне политических перипетий того времени. В каждой из перечисленных глав показано как ВШП влиял на формирование внешней политики как глобальных политических игроков, контролировавших основные маршруты этого пути, так и тех небольших стран и государств, которые располагались на тех или иных участках этого пути. В каждой из глав имеются карты местных маршрутов и показаны как они соединяются с главными магистральными направлениями Шелкового пути того или иного исторического периода. Значительное место в книге уделено освещению южнокавказского участка Прикаспийского пути, который соединял страны Ближнего Востока с Северным Кавказом и Поволжьем.

Также широко освещена проблема городов, функционировавших на маршрутах Шелкового пути. Показывается как формировалась инфраструктура этих городов, их историкоархитектурный образ, как в тот или иной исторический период развивалось городское ремесло и торговля, как Шелковый путь благотворно влиял на развитие традиционных и возникновению новых отраслей ремесла, рассматривается структура импорта и экспорта, ассортимента товаров и его изменения в том или ином историческом периоде. Например, очень удачно показано как Азербайджан из потребителя китайского шелка в античную эпоху, в период средневековья становится одним из активных производителей и экспортёров шелка во многие страны Европы и Востока. Много внимания в книге уделено монетарному обеспечению торговли Азербайджана по Шелковому пути в период античности и средневековья.

Особо обращает на себя внимание достигнутый авторским коллективом удачный синтез письменных источников с обширным археологическим и нумизматическим материалом. Книга богато иллюстрирована многочисленными изображениями памятников архитектуры и находок, показывающими огромное значение Шелкового пути в формировании материальной и духовной культуры азербайджанского народа.

Разумеется, в одной рецензии трудно полностью раскрыть ту обширную научно-историческую информацию, которую содержит это понастоящему академическое издание, посвящённое истории Шелкового пути на фоне истории одного государства. Совершенно очевидно, что пока это одна из очень немногих работ такого рода, введённая в научный оборот за все время исследования проблем, связанных с изучением ВШП, начиная с конца прошлого столетия, т.е. с периода начала реализации международной программы ЮНЕСКО «Комплексное исследование Шелкового пути - пути диалога».

Прежде всего, хочу поздравить наших азербайджанских коллег с выходом в свет такого обстоятельного исследования, изданного сразу на двух языках (английском и русском, готовится к изданию и на азербайджанском языке), и, надеюсь, что их пример будет, в хорошем смысле этого слова, «заразительным» для всех, кто занят изучением проблем Шелкового пути. 